\title{
Memória, Narrativas e Emoções: breves considerações sobre o luto
}

Luiz Gustavo Pereira de Souza Correia ${ }^{1}$

\section{Resumo}

Este texto tem como objetivo compreender as vivências dos processos simbólicos e as interpretações pessoais sobre a perda da visão via narrativas de indivíduos cegos habitantes de Porto Alegre, Rio Grande do Sul. As abordagens são voltadas às temporalidades diversas emaranhadas nas memórias dos personagens e recompostas nas suas narrativas. As emoções expressas nas narrativas são os elementos de análise e compreensão das elaborações simbólicas dos personagens da sua localização e orientação social como indivíduos cegos em um cenário urbano.

Palavras-chave: luto, emoções, memória, narrativas, sociabilidade urbana.

\section{Memory, Narratives and Emotions: brief remarks about mourning}

\begin{abstract}
:
The aim of this text is to understand the experiences of symbolic processes and personal interpretations about loss of vision by narratives of Porto Alegre's blind inhabitants. The comprehensive approaches follow the several temporalities matted in characters memories and the expressed emotions in their narratives. The emotions expressed in the narratives are the elements to analyze and understand symbolic elaborations made by charac-
\end{abstract}

1 Doutor em Antropologia Social. Professor do Departamento de Ciências Sociais e do Programa de Pós-Graduação em Antropologia da Universidade Federal de Sergipe. Email: luizgustavopsc@gmail.com 
ters to explain their social localization and orientation as blind individuals in a urban setting.

Keywords: mourning, emotions, memory, narratives, urban sociability.

0 foco deste artigo é dirigido às construções narrativas sobre o luto, entendido como um processo de transição e de reconfiguração social do indivíduo em que a percepção e a reflexividade se revelam intensamente. 0 objetivo do texto é discutir as narrativas de um personagem central da pesquisa de doutoramento em Antropologia Social que buscou compreender as elaborações simbólicas sobre a perda da visão, desenvolvida junto a moradores de Porto Alegre, Rio Grande do Sul (CORREIA, 2007). A discussão gira em torno da tessitura das lembranças e dos silêncios da memória no ato de rememorar, a atribuição de sentidos aos acontecimentos passados em que o personagem narrativo, o si-mesmo do narrador (RICOEUR, 1988, 1991, 1994), está enredado.

As temporalidades próprias do luto são analisadas na busca por compreender de que maneira se dá a ruptura, o isolamento voluntário e a recomposição dos laços sociais que situam o indivíduo na sociedade. O luto é aqui percebido como uma passagem, no sentido atribuído por Van Gennep (1978), processo em que há uma mudança na localização social do indivíduo, uma transição que se dá através das fases de suspensão, liminaridade e reincorporação do indivíduo pelo grupo. Seguindo os desdobramentos da conceituação de liminaridade por Turner (1974) nas análises dos ritos, o luto pode ser pensado então como um processo em que a fase liminar se reflete nas incertezas e apreensões vividas, na marginalidade e na ambiguidade circunstanciais (DAMATTA, 2000), nas tensões e riscos em que se percebe o indivíduo devido às rupturas na sua história biográfica.

0 luto pode ser ainda analisado como processo fundamental de "retomada do controle de si próprio" onde se estabelece um 
"novo sentido do eu", um "novo sentido de identidade", utilizando-se das palavras de Giddens (2002, p. 18). Isto porque a individuação, etapa crucial do luto, caracteriza-se pelo distanciamento voluntário do indivíduo dos seus quadros de relação social, como restrição ou contenção das expressões de sofrimento por parte dos sujeitos nas sociedades contemporâneas. Tal processo é entendido como momento de intensificação de um aspecto que marca as relações sociais nas sociedades ocidentais, a busca por "encontrar-se a si mesmo", "um processo de intervenção e transformação ativas", citando novamente Giddens (Idem, p. 19).

São então apresentadas algumas narrativas de Anderson ${ }^{2}$ sobre a sua própria experiência, pontuadas com relatos de outros personagens da pesquisa, como construções discursivas que se apropriam das vivências pessoais e as expressam em uma "configuração saturada de tensões" (BENJAMIN, 1994). As emoções expressas nas narrativas, tais como o sofrimento, a vergonha, o medo e seus contrapontos reativos, são compreendidas e analisadas como construções intersubjetivas a partir das composições em que eventos significativos, marcos das histórias pessoais dos personagens, são relacionados às suas novas localizações e orientações sociais.

\section{Passagens de campo e narrativas}

O contato com Anderson deu-se pelo fato dele ser cliente do Centro Louis Braille, instituição onde foi desenvolvida parte da pesquisa. 0 Centro Louis Braille, ou Centro de Educação e Reabilitação Louis Braille para Pessoas com Deficiência Visual, é uma unidade constituinte da FADERS, Fundação de Articulação e Desenvolvimento de Políticas Públicas para Pessoas Portadoras de Deficiência e Pessoas Portadoras de Altas Habilidades no Rio Grande do Sul. Entre suas atribuições, desenvolve 
as atividades de Ensino do Sistema Braille, Ensino do Soroban, Orientação e Mobilidade, Atividade da Vida Diária, Informática adaptada para Deficiente Visual e Atividades Físicas Adaptadas, além de manter grupos de convivência, Psicoterapia, Assistência Social, encaminhamento para estágios e produção de material em Braille. Oferece ainda uma série de oficinas, tais como Sensibilização Através da Arte, Práticas e Percepções para Deficientes Visuais e promove atividades de pesquisa e capacitação em parceria com instituições, escolas públicas e privadas e empresas.

À época da pesquisa, Anderson tinha 38 anos. Dezessete anos antes havia sofrido um acidente de carro que o fez perder quase completamente a visão. Um ano e meio depois do acidente, procurou o Centro Louis Braille, quando frequentou o treinamento para execução de atividades domésticas e ambientes internos - o curso de Atividades Diárias - para locomoção e atividades em ambientes externos - Orientação e Mobilidade - além do curso de softwares de informática específicos e a aprendizagem da escrita Braille. Nesta época ainda ele fez algumas sessões de psicoterapia, mas interrompeu as visitas antes do período recomendado pela psicóloga do Centro. Após 15 anos afastado do Louis Braille, Anderson voltou a procurar o atendimento psicológico e o treinamento de Orientação e Mobilidade por conta da perda do mínimo de visão que lhe restava até o ano de 2003.

Durante as entrevistas, Anderson, ao se perceber reconstruindo ou recompondo o emaranhado de emoções e sentidos em jogo no decorrer da sua vida, expunha a emergência de uma temporalidade diferenciada, uma fase de incertezas e negociações de papéis a partir dos acontecimentos narrados. Os eventos narrativos abriam novamente diferentes perspectivas e indefinições no processo em andamento. A mudança de localização social era evidenciada nos termos da expectativa da nova circunstância corporal, do estranhamento e do conflito com a auto-imagem, o distanciamento voluntário do mundo de referências. Isso ilustra a reflexividade da circunstância em que se coloca ao narrar 
sua experiência e revela alguns dos sentidos da sua passagem. A reconstrução narrativa das etapas vividas no processo expõe a construção temporal do luto:

Olha, em 2000, há quatro anos atrás, eu fiquei meio... era eu e eu mesmo dentro de casa só, trancado, não queria saber de nada, foi auge de deprê mesmo, ali foi feio, a coisa tava meio complicada, era... tudo, bah, era quase como um... eu queria me afastar de tudo, de tudo, tudo, tudo mesmo que tava ao meu redor, era meio por uma dificuldade de lidar com aquilo que tava acontecendo comigo. E vou te dizer, ainda hoje eu tenho dificuldades em algumas coisas e ainda me recolho... Então o problema assim é realmente como lidar com as coisas. E eu ainda tô num processo, ainda vejo assim que não tô muito sano, mas tá bem melhor. Até assim, de reconhecer que o problema de fato não tá fora de mim... realmente eu acho que o principal é conseguir encarar de forma melhor, é uma coisa interna, é uma coisa meio difícil de explicar. É reconhecer que o problema tá em si e tentar mudar, encarar melhor as situações... Mas é assim, é bem interno mesmo...

Ao revelar a vontade de distanciamento do seu universo de relações sociais, Anderson pareceu expor de forma clara a individuação como primeiro instante de ruptura, como corte brusco no desenrolar dos projetos de vida, momento liminar de em que busca aprender "como lidar com as coisas". Instante de afastamento do jogo social como internalização do sofrimento, caracterizando a solidão como maneira de expressão de uma necessária reclusão sentida como segurança pessoal, como ação de resguardar a intimidade dos olhares alheios. Tais são as indicações de Todorov, quando afirma que a solidão "não significa que podemos dispensar os outros nem que não nos interessamos por eles" (1996, p. 158). Continua ainda o autor propondo que "na solidão, não deixamos de nos comunicar com nossos semelhantes, apenas escolhemos algumas formas de comunicação em detrimento de outras" (idem). Em tal proposição, portanto, destaca-se o aspecto social do isolamento, a expressão da necessidade de sentir-se sozinho 
como busca por segurança. A forma como Anderson abordou o sofrimento na sua narrativa remetia à sensação de incapacidade de compartilhamento da dor com os outros. A intensidade da dor como sentimento disperso e confuso, sentido como único, pessoal, expresso em termos de constrangimento e sensação de inadequação e insegurança em circunstâncias de sociabilidade. O sofrimento exposto mesclava a frustração em relação a expectativas e projetos pessoais e a sensação de incapacidade de efetivação de tais ações sociais com um movimento solitário de introspecção e internalização da dor. Parecia haver para Anderson uma censura voluntária em relação à exposição do seu sofrer, "eu queria me afastar de tudo, de tudo, tudo, tudo mesmo que tava ao meu redor, era meio por uma dificuldade de lidar com aquilo que tava acontecendo comigo".

0 isolamento da dor pessoal em um processo solitário de individuação justapõe a perda de sentido do mundo e o sentimento de desvinculação das relações sociais nos conteúdos subjetivos conformadores da individualidade. Diferente do que propõe Mauss (1979) ao falar da expressão obrigatória de sentimentos durante ritos funerários em sociedades tradicionais, a individuação revela uma outra economia emocional ou conjunto de regras de etiqueta apreendido nos centros urbanos contemporâneos, nos termos de Elias (1995; 2001). Elias foi um dos pioneiros na elaboração das emoções - em especial a vergonha - como foco de análise das sociabilidades (ELIAS, 1994; 1995). Neste sentido, percebe a autoimagem de indivíduos e grupos ligados às processualidades próprias desenvolvidas em suas histórias relacionadas às configurações sociais como referências de si e dos outros em interação e interdependência no jogo social. A relação entre indivíduo e sociedade se encontra imbricada pelos vínculos dos sentimentos individuais e as figurações em que se efetivam nas esferas sociais. Noções como orgulho e vergonha possibilitam a compreensão dos conflitos entre as autoimagens grupais e pessoais na dinâmica da sociedade. A retração à subjetividade e a falta de expressão dos impulsos afetivos levam a um afastamen- 
to entre o que é percebido como o mundo interno do sujeito e a sociedade. Como afirma Elias,

Esse conflito no indivíduo, essa "privatização" - a exclusão de certas esferas de vida do intercâmbio social e sua associação com uma angústia socialmente instilada, como os sentimentos de vergonha ou embaraço -, que desperta no indivíduo a sensação de ser, "internamente", uma coisa totalmente separada, de existir sem relação com as outras, relacionando-se apenas 'retrospectivamente' com os que estão 'fora' dele (ELIAS, 1994, p. 103).

O luto pode então caracterizar-se como processo de isolamento agudo do indivíduo em relação aos círculos sociais em que mantém contatos e intercâmbios pessoais. Tal como afirma Koury, o luto surge para o sujeito na sociedade contemporânea "como consequência de sua subjetivação e falta de expressão no social, e pela ambivalência resultante na vergonha como individuação, reprovação e estranhamento público" (1996, p. 35). A tendência ao processo solitário do sofrimento, sem exposição às esferas sociais dos sentimentos de dor ou pesar, tem como base o conjunto de códigos de conduta e etiqueta incorporado pelos sujeitos (ELIAS, 1994; 2001). A manifestação social das emoções, como o sofrimento e a aflição, vai se transformando em elemento estranho ao cotidiano dos sujeitos urbanos. Assim, a idéia do fracasso, da desilusão no ritual introspectivo da dor, impõe códigos de anonimato ao processo social da perda, evidenciando a fragmentação de sentimentos coletivos que se expressam em uma espécie de receio de contaminação e na vergonha de se sentir em luto (KOURY, 1996; 2005).

Como característica das sociedades contemporâneas, a motivação para preservar um mundo interno, subjetivo, do mundo externo, ou social, é sentido nos contatos com os demais sujeitos nos cenários urbanos, percebidos como estranhos, anônimos. 
Um outro cliente do Centro, Rogério, abordou a perda da visão também relacionando à vergonha e à insegurança vivenciadas no cotidiano. 0 ex-taxista, à época com 35 anos, morador da zona metropolitana de Porto Alegre, havia nove anos que tinha perdido a visão em decorrência de problemas congênitos e frequentava o Louis Braille havia dois anos. Em sua narrativa, o medo e a vergonha surgem como aspectos relacionados às formas de sociabilidade e o uso dos espaços urbanos pelos habitantes da cidade:

Os primeiros cinco anos foi terrível, né, terrível. Eu tentava não demonstrar isso, tentava não demonstrar, ficava mais doído por dentro e agora nesses dois anos em diante a coisa melhorou pro meu lado, sabe. Eu tô mais confiante, vamo dizer, de primeiro eu tinha vergonha de mostrar a bengala, né. Bah, Deus o livre, antes eu ia pro Braille e vinha com ela fechada, e tu viu, né, essas calçadas daqui do bairro são umas porcaria. Eu descia do ônibus e ia pelas calçada bem devagarinho, tentando caminhar sem a bengala. Eu tinha vergonha, sabe. Eu creio que... eu acho que de repente.. como eu te disse, que eu sempre tenho uma esperançazinha, e isso aí me dificulta de repente um pouco, sabe. Se largasse isso aí um pouco... mas também pensando, a gente não pode viver sem esperança, sem esperança a gente não é ninguém, né. E daí eu sempre tenho a esperança e creio que isso me dificulta um pouco. (...) Esses cinco anos, a dor da perda eu tentava não expor tanto. Eu botava pra fora mais com a minha mulher $e$ com o meu filho. E pra vizinhança eu ficava mais calado, eu tinha vergonha, tinha mesmo. Agora até nem tanto, mas, bah, nesses cinco aí tinha vergonha, né. Eu andava com a bengala fechada. Eu hoje quando ando com a mulher eu ando com ela fechada, mas sozinho eu ando com ela aberta, pra me identificar, né. (...) Eu me identifico sozinho. Quando eu tô com ela eu prefiro andar com ela fechada, não sinto insegurança, não, eu me sinto mais à vontade. Porque eu fico pensando que tem muito batedor de carteira no centro, né. E os cara vê, 'bah, esse cara é cego, é uma barbada, né.' E eu fico pensando,de repente, pra evitar isso, né. Eu creio que uma pessoa com deficiência é mais fácil pro cara”. 
Essa fala de Rogério abre a possibilidade de uma rápida discussão sobre as emoções medo e vergonha como construção social e as interações intersubjetivas dos indivíduos que perderam a visão. Em tal narrativa, o medo e a vergonha surgem como aspectos relacionados às formas de sociabilidade e o uso dos espaços urbanos pelos homens comuns e habitantes da cidade (KOURY, 2002, 2005; MARTINS, 1999, 2000).

0 medo tem o aspecto de vivência cotidiana de sinais de reconhecimento dos sujeitos urbanos por si próprios e da imposição da semelhança ou da distância em relação aos demais. Dessa forma, é percebido, agenciado e objetivado como possibilidade de enlace ou conflito, mas sempre como elemento compreensivo e organizativo dos processos individuais e coletivos no jogo social. O medo, assim, pode ser compreendido não apenas como uma ameaça ou uma insegurança sentida e expressa pelos sujeitos, mas também como fatores envolvidos em novas possibilidades reativas de articulação social. Ao falar da sua percepção como sujeito exposto à violência cotidiana dos centros urbanos, ainda que não relate uma agressão efetiva, Rogério revela as tensões no seu caminhar e na identificação como cego. Tais sujeitos, como "os outros" a partir dos quais se dá a identificação pessoal, são percebidos como fontes ou encarnações do medo cotidiano. É através dessa interação no dia a dia que se estabelecem as formas como os sujeitos negociam seus papéis. Tendo a desconfiança e o receio em relação ao que pode esperar do outro e, ao mesmo tempo, como se portar diante do outro, as trocas corriqueiras fundam e dão suporte a códigos de conduta.

O medo, dessa forma, é percebido, agenciado e objetivado como possibilidade de enlace ou conflito, mas sempre como elemento compreensivo e organizativo dos processos individuais e coletivos no jogo social. 0 discurso de Rogério, carregado de tensões e conflitos pelo sofrimento solitário expresso em passagens como "a dor da perda eu tentava não expor", ou "ficava mais doído por dentro", pela vergonha, "pra vizinhança eu ficava mais calado, eu 
tinha vergonha, tinha mesmo", e pelo medo, "porque eu fico pensando que tem muito batedor de carteira no centro, né. E os cara vê, 'bah, esse cara é cego, é uma barbada, né", exprime as impressões e ações significativas vividas por ele e como pensa seu sentido de individualidade nos jogos sociais do cotidiano.

Tal apreensão também é manifestada na fala de Anderson relatada a seguir. Além da desconfiança dos outros, do tensionamento e do conflito frequentes como formas sociais de interação, ele narra o sentimento de estranhamento para consigo próprio. As incertezas presentes na liminaridade do luto eram sentidas como medo da sua nova condição:

Eu imaginava assim, "não, isso não tá acontecendo de verdade, é uma brincadeira!". Eu tinha que fazer uns exercícios mentais assim, porque senão eu ficava pirado, embora tenha sido uma certa piração, porque eu não tava encarando a verdade. E, bom, falando assim essas coisas tu deve pensar assim, "esse cara é meio louco mesmo!"... E, cara, eu falando assim eu vejo o festival de bobagens que eu tenho na minha cabeça de coisas ruins, chatas, desagradáveis e fantasmas que eu mesmo criei. (...) Eu não vejo um processo pronto, ainda tá... bom até hoje eu tento... é uma dificuldade de aceitar pra mim mesmo, de reconhecer... pior que já faz um tempão, dezesseis anos e ainda tá aí, né? No início eu tinha muita vergonha de reencontrar as pessoas, colegas, amigos e tal... e, bom, hoje eu procuro levar uma vida menos pesada em relação a eu comigo mesmo, ser uma coisa mais leve. Eu acho assim, que um exercício que eu fiz foi tentar ver assim, se eu me colocar na situação oposta... a impressão que eu tenho é que as pessoas em geral, passado o impacto inicial, elas não têm uma dificuldade grande de lidar assim, de ver, de conviver com alguém que não enxerga, e eu via que o problema era mais interno meu, tava mais comigo...

Essa passagem mostra o que parece ser a vivência de uma situação ambivalente por parte de Anderson, na medida em que não encontrava a solidariedade esperada - apesar de não sentir que 
sofre um isolamento total ou repulsa por parte dos seus entes próximos - e a intenção de se recolher em um sofrimento solitário, como imposição de uma autocensura. 0 desconforto e a tensão provocados pela sensação de desajuste da autoimagem em relação ao mundo externo se estabeleciam como expressão para si próprio do sofrimento e do receio que a perda da visão lhe proporciona. A "vergonha de reencontrar as pessoas, colegas, amigos e tal..." contada por Anderson surgia como reflexo desse processo. Para ele, a perda da visão e os seus sentidos deviam ser elaborados como problemas de ordem interna, privada. Não convinha a ele a exposição das dúvidas e receios que os efeitos do acidente lhe trouxeram. Não cabe aos outros, sejam pessoas do seu convívio mais íntimo, ou mesmo desconhecidos, tomar parte nesse momento da sua vida.

Bom, uma coisa assim que teve, pra até desmistificar, no início o que eu pensei que tinha comigo era assim tipo um... Pode até ser uma forma de encarar a realidade... Parecia ser meio um sonho, um pesadelo, o que tava acontecendo e eu achei que poderia haver uma mudança muito grande, assim como se eu não fosse mais eu mesmo. E aí eu fui vendo assim que conhecendo outras pessoas, porque eu achava que tinha também, assim... É, cara, falando assim contigo eu recupero coisas que meio que tinha colocado pra baixo do tapete $e$ volta e meia, assim, exalam um mal-odor... Que era o seguinte, volta e meia eu via pessoas vendendo loto, e eu achava que o meu futuro ia ser esse, vender loto... Eu sei lá, vou ser um coitado. E era isso que eu pensava de mim mesmo. É diferente, tu tá de fora de uma situação e não é só de que lado tu tá, mas sim como tu sente aquela situação... Aí depois eu conheci caras que eram cegos e vendiam loto e eu vi uma coisa completamente diferente... E, bom... Falando assim contigo eu vejo que eu mesmo me coloquei uma série de limites, de limitações e até hoje eu tenho uma dificuldade de lidar com isso, mas, guardadas as proporções, eu acho que a mesma coisa que as pessoas pensam em relação a mim, das pessoas poderem se afastar pelo fato de eu não enxergar, eu também me afastei de mim mesmo por não enxergar. Pelo fato de eu não me aceitar. 
0 estranhamento e o conflito com sua autoimagem e em sua relação com a sociedade ficam claros em passagens como quando Anderson afirma, "eu achei que poderia haver uma mudança muito grande, assim como se eu não fosse mais eu mesmo" ou ain$\mathrm{da}$, "eu acho que a mesma coisa que as pessoas pensam em relação a mim, das pessoas poderem se afastar pelo fato de eu não enxergar, eu também me afastei de mim mesmo por não enxergar. Pelo fato de eu não me aceitar". Para em seguida relatar como se deu o encontro com outros clientes no Centro Louis Braile: "Aí depois eu conheci caras que eram cegos e vendiam loto e eu vi uma coisa completamente diferente... É diferente, tu tá de fora de uma situação e não é só de que lado tu tá, mas sim como tu sente aquela situação..."

A mudança de localização social fica evidenciada nos termos da expectativa da nova circunstância corporal, do estranhamento em relação si próprio, o distanciamento do universo de relações sociais. A crise é exposta "como um sonho, um pesadelo", um período em que Anderson sentia-se em transformação, sem saber ao certo como agir ou que papel assumir e, principalmente, como sair dali. 0 período de resolução ou entrada em uma nova esfera de intersubjetividades é visto retrospectivamente como uma fase de encontro com uma nova perspectiva de vida social.

A narrativa de Anderson expõe e contrasta a relação entre o ontem e o hoje vividos por ele e as elaborações daí decorrentes pela interpretação das suas experiências. Tal como a função da decupagem e da montagem na criação do tempo narrativo cinematográfico, as fusões, pausas e cortes dos relatos aqui apresentados demonstram o ritmo da introspecção - o mergulho na própria experiência, nas palavras de Benjamin (1994) e da expressão na construção do si-mesmo como personagem da narrativa. Nestas junções e rupturas do relato se inserem temporalidades diversas costuradas pelo narrador no instante presente voltado aos acontecimentos passados, compondo a trama em que o personagem se percebe enredado. Tais narra- 
tivas, citando as indicações de Bauman, surgem "as a means of giving cognitive and emotional coherence to experience, constructing and negotiating social identity" (1986, p. 113). Isto porque as experiências vivenciadas são expostas como um processo em contínuo devir, indeterminado e sem um fim traçado, com rupturas e afastamentos, bem como reencontros e vinculações. Como personagem de um drama social no processo do luto, ele se insere na tensa relação em que os sentimentos são experimentados mas também contidos em sua expressão pelo constrangimento estabelecido pelos códigos do que é socialmente compartilhável.

Ao se perceber reconstruindo ou recompondo o emaranhado de emoções e sentidos em jogo no decorrer da sua vida social, Anderson expõe a emergência de uma temporalidade diferenciada, uma fase de incertezas e negociações de papéis a partir do drama social narrado por ele. 0 evento narrativo, assim, parece abrir novamente diferentes perspectivas e indefinições no processo em andamento. Ao afirmar, "É, cara, falando assim contigo eu recupero coisas que meio que tinha colocado pra baixo do tapete e volta e meia assim exalam um mal-odor...", Anderson evidenciou a consciência da ruptura com a experiência cotidiana para a entrada na temporalidade do ato narrativo. $\mathrm{Ou}$ ainda no trecho em que disse, "Falando assim contigo eu vejo que eu mesmo me coloquei uma série de limites, de limitações e até hoje eu tenho uma dificuldade de lidar com isso" ilustra a reflexividade da circunstância em que se coloca ao narrar sua experiência.

Um outro aspecto presente nas entrevistas com Anderson indica a relação entre a perda da visão no acidente de carro - e o processo de luto daí decorrente - e o sentimento de vergonha por conta do sofrimento e da sensação de inadequação. Elemento revelador de outra etapa do processo de assimilação e negociação de uma nova identidade, a vergonha surge nos momentos de interação social. 
A culpa parece ficar atrelada a impressões como a seguinte:

E eu acho que assim, bah, um lance que eu pensei durante um tempo e até hoje de vez em quando eu tenho umas recaídas é que eu acho que foi uma grande cagada que eu fiz... o acidente, então... Hoje eu vendo assim, olha, muita coisa, eu acho que eu podia ter... bem, a essa altura do campeonato não adianta mais nada... eu podia ter feito diferente, mas tá feito... Então eu acho que é uma coisa interna minha, é um problema emocional meu, e isso é crônico, é uma instabilidade...

Dessa forma, o acidente, como estopim do processo desencadeado, é tecido nas falas com o peso da culpa. Culpa, assim como me falou em outros momentos Anderson, pelo erro cometido, pela "frustração" causada em relação aos planos e "expectativas da família", pela "limitação" que se imputou.

A vergonha, por seu turno, é experienciada nas ações sociais. Como embaraço pela falta de habilidade exigida aos olhos dos outros e como receio da demonstração pública do sofrimento e da perda da visão. Elemento intimamente ligado à perda da visão e às interpretações sobre a nova identidade social negociada, a emoção vergonha, discutida aqui como um sentimento revelador dos contatos entre os indivíduos. A vergonha surge pelo desconforto sentido pela aparente inadequação do sujeito ao seu universo de relações sociais.

Assim, só pode ser entendida a vergonha como um sentimento relacionado a um processo conflitante e tenso vivido pelo indivíduo na vida cotidiana, como uma construção social. Como alguém que não encontra seu lugar próprio nas redes de sociabilidade estabelecidas no jogo social, o indivíduo tende a retrair-se e isolar-se. É o que afirma Martins, para quem “o olho dos outros é a medida. A vergonha aparece pelo fato de a autoridade externa estar interiorizada e vem do reconhecimento da validade da autoridade externa por parte dos membros da comunidade" 
(2000, p. 25). A individualização leva o sujeito a se pensar como unidade consciente e responsável pelas suas ações com maior independência e liberdade nas suas relações sociais. 0 que a vergonha expõe é a sensação de frustração do sujeito por não conseguir agir satisfatoriamente nas diversas situações impostas pelos grupos a que vê necessariamente vinculado o seu projeto de vida. Isto é, seu "eu interno" parece não encontrar espaço adequado para agir e conviver no ambiente "externo" em que se relaciona (ELIAS, 1994).

As tensões e conflitos relatados pelos clientes, percebidos nas esferas sociais mais públicas ou mesmo privadas do cotidiano, ressaltavam as vivências individuais dos processos de elaboração da perda da visão. As entrevistas realizadas ainda com outros clientes do Centro direcionavam as observações às interpretações individuais expressas nas narrativas, mais que a uma discussão dos sentidos de uma identidade grupal ou de um sentimento de pertença coletivo. Mesmo em meio às práticas cotidianas desenvolvidas com certa frequência e em um período de tempo relativamente longo por grupos específicos, ou mesmo entre clientes com histórico de vários anos no Centro, nunca parecia estar em construção uma memória coletiva.

A fragmentação e a individualização da vida urbana ficavam marcadas pelos significados atribuídos à perda da visão nas falas dos clientes do Centro. Assim, como um local onde se estabelecem formas de sociabilidade urbanas, com movimentos e rupturas contínuas, o corpo de entrevistas realizado no Louis Braille encaminhava a investigação sobre os sentidos acerca da perda da visão para as vivências individualizadas do luto e das reconfigurações corpóreas e subjetivas. Os sentidos envolvidos no projeto de vida dos clientes, quando este é rompido pela cegueira, são percebidos a partir de um afastamento do sujeito da vida social, do mundo externo. Eram recorrentes narrativas sobre o processo de distanciamento, a quebra de sentidos compartilhados de afetos e ações no mundo, revelados no isolamento 
individual e na barreira emocional estabelecida entre o sujeito e o mundo. A perda da visão acarretava conflitos e distanciamentos dos sujeitos de suas esferas de pertença e do rompimento dos laços até então compartilhados.

Tais reflexões encontram eco nas narrativas de outros personagens. Como na fala de Tiago, cliente do Centro que perdeu a visão em um acidente de carro, um jovem de vinte anos à época do contato rápido em frente ao Louis Braille:

Com a perda visão eu fiquei muito revoltado. A gente passou muito trabalho lá em casa. Eu briguei muito, eu xinguei muito, eu rejeitei muito. Meus amigos dizem que eu vivia num caramujo, eu vegetava, não vivia.

Essa é ainda a interpretação de Lísia, cliente do Centro Louis Braille com 34 anos na época da pesquisa, quando narra momentos específicos do seu processo, o instante em que soube que ficara cega:

A partir dali eu não tinha mais recuperação, o médico disse que eu não tinha mais chance. Aí eu tive de aguentar. Eu fiquei muito deprimida, durante dois anos, não saí de dentro de casa, não conseguia fazer nada. Eu achava que não ia conseguir. Como muitos não aceitam quando perdem... Aí nisso eu fiquei dois anos. Hoje eu me sinto muito bem, conheço as pessoas daqui, e mesmo sem ter a visão eu percebi que era ainda um ser humano. Mas eu me sentia rejeitada, eu não me aceitava, então eu fazia com que as pessoas se afastassem de mim.

Tais percepções convergem com a afirmação de Koury, para quem a emoção vergonha é vivenciada de duas formas simultâneas, como "sentimento penoso de desonra e de inferioridade frente a um outro" e como "receio de exposição e de ser objeto de 
juízo de um outro" (2003, p. 27). Isto ficava marcado nas falas relacionadas aos primeiros deslocamentos em locais públicos e aos treinamentos iniciais para o uso da bengala. 0 Centro era tido nas falas como marco de um processo carregado de tensões, na medida em que representa alguns dos primeiros contatos com espaços e indivíduos fora do âmbito familiar ou socialmente restrito, um momento de exposição da nova condição corpórea para o mundo, a sociedade mais ampla. "A vida sem sentido", "o mundo que desaba", entre outras expressões de ruptura com o projeto de vida anteriormente configurado utilizadas para expressar o sentimento relacionado à perda da visão, são representativas da percepção do sentido ligado a si como um sentido estritamente individual, incomunicável e íntimo. A vergonha, o medo e o estranhamento são indícios da individualização no jogo social, da forma privada de lidar com o sofrimento e o luto pela perda da visão.

O embaraço pela exposição de uma fragilidade frente às ameaças do cotidiano simbolizada no manuseio da bengala, bem como outras impressões relatadas, seja de afastamento das pessoas entendido como "medo de contágio" ou ainda a incapacidade de prover financeiramente a família, são faces da sensação de inadequação frente às tarefas necessárias para a plena inserção no jogo social. "A rua como espaço próprio do olhar que esvazia o corpo" (MARTINS, 1996) tem como sintoma o si-mesmo como estranho. 0 estranhamento em relação à reconfiguração corpórea passa pelo deslocamento do lugar próprio no mundo ao não compartilhar símbolos e elementos visuais, o corpo percebe na nova relação com o mundo o espaço público como espaço do medo, do não familiar. Esse sofrimento íntimo, a vida que perdeu o sentido, é o reflexo das formas de interação e economia emocional das sociedades contemporâneas captado pelas pessoas que perderam a visão. A ruptura de um projeto de vida, percebido unicamente como individualizado e separado do mundo externo, causa no mundo íntimo do sujeito a impossibilidade de compartilhamento de sentidos. 
Assim conta Anderson a sua experiência:

Até pras outras pessoas saberem como se comunicar, é uma forma de tu... é assim, deixa eu te dizer... E, então, assim, na questão da reabilitação, no início pra andar na rua de bengala, era complicado. Eu imaginava assim, "não, isso não tá acontecendo de verdade, é uma brincadeira!". No início pra mim foi muito difícil usar a bengala, fazendo uma análise fria de como foi o meu processo de readaptação, eu tive uma dificuldade muito grande de aceitar. E aí eu pensei durante um tempo assim: 'Mas vem cá, por que eu discriminava?', 'Eu não gostava de uma pessoa cega por que eu discriminava também?'. E eu fiquei assim pensando, 'Olha, ajudei pessoas na rua, a atravessar a rua quando eu enxergava' e acho que a questão é... Não sei, me parece assim, a dificuldade de ser aceito... [pausa] Eu me sentia muito diferente, cara... É uma coisa muito estranha assim de se dizer... [pausa] Era difícil me aceitar nessa condição. Por dois lados, uma que eu tava muito diferente pra mim mesmo e outra que eu achava, e é um fato, que eu tava muito diferente pro resto das pessoas também. Porque... É uma coisa assim...Não é... Agora... Ehh... Eu percebo assim que tem coisas, eu não sou uma pessoa completamente adaptada, aceitando a minha situação, mas procuro... É complicado ainda pra mim... E... [pausa] Pra tu ter uma ideia, a primeira vez que eu fui num bar sozinho foi em 2000, a primeira vez que eu me lembro assim foi em 2000, então depois de quase doze anos depois da cegueira. E às vezes ainda é complicado... Então assim, eu falei isso porque é... tipo, eu vivo ainda num processo de convívio comigo mesmo. Que era o seguinte, volta e meia eu via pessoas vendendo loto, e eu achava que o meu futuro ia ser esse, vender loto... Eu sei lá, vou ser um coitado. E era isso que eu pensava de mim mesmo. Aí depois eu conheci caras que eram cegos e vendiam loto e eu vi uma coisa completamente diferente... Eu me lembro de uma vez de ter ajudado um cara a atravessar uma rua aqui no Centro, me dispus a caminhar, porque tava no meu caminho, e eu perguntei a ele o que fazia e ele, "massagem", perguntei onde ele trabalhava e tal. Eu pensei, bom, o cara tá na luta, mas, bah, é uma limitação muito grande e ainda hoje eu acho, é uma limitação porrada. 
Giddens (2002), ao tratar da vergonha, destaca dois aspectos que tal sentimento revela. Em primeiro lugar a falta de confiança nas condições de efetivação do projeto de vida, da integridade da identidade pessoal, a insegurança em relação à concretização do seu eu. E também por ser estruturada nas relações com os demais atores sociais, a vergonha surge no embaraço do sujeito, na visibilidade do seu constrangimento refletido no corpo, nos gestos, nas posturas e nas falas como ações e expressões simbólicas. Tal conceituação da vergonha toca em dois pontos salientados nas entrevistas de Anderson. 0 primeiro é a relação entre a corporeidade e o sentimento de vergonha, ou como os padrões de comportamento são apreendidos, percebidos e expressos nas interações cotidianas. Outro ponto é a perda da visão percebida como impossibilidade de concretização do projeto de vida.

De tal maneira, as emoções relacionadas ao luto - a dor e o sofrimento solitário na individuação e a vergonha como experiência corpórea e subjetiva na nova configuração e orientação social do sujeito - são elementos reveladores das temporalidades e processos pessoais nas trocas intersubjetivas nas sociedades contemporâneas. Seguindo as impressões de Anderson, seja na vontade expressa de "afastar de tudo, de tudo, tudo, tudo mesmo que tava ao meu redor", seja na "vergonha de reencontrar as pessoas", ou ainda nas dificuldades de se reconhecer em ações corriqueiras como andar na rua ou ir a bares, o pesar e a vergonha são sentimentos de difícil expressão no jogo social, são aspectos recolhidos à segurança da subjetividade, contidos no mundo íntimo da individualidade.

\section{Considerações finais}

A fragmentação e a individualização da vida urbana ficavam marcadas pelos significados atribuídos à perda da visão nas falas dos clientes do Centro. Assim, como um local onde se estabelecem formas de sociabilidades urbanas, com movimentos e 
rupturas contínuas, o Louis Braille encaminhou a investigação sobre os sentidos acerca da perda da visão para as vivências individualizadas do luto e das reconfigurações corpóreas e subjetivas. Os sentidos envolvidos no projeto de vida dos clientes, quando este é rompido pela cegueira, são percebidos a partir de um afastamento do sujeito da vida social, do mundo externo. As falas revelaram o aspecto de "sentir-se estranho" ou "sentir-se um estranho" na intimidação e no medo de rejeição sentidos e provocados nas caminhadas. Seja como retraimento ou como distanciamento voluntário das demais pessoas ou como busca por aproximações ou semelhanças, nas possibilidades de socialização e de conformação de novas articulações e redes de interação, o estranhamento é percebido como elemento presente no jogo social. Dessa forma, as noções de medo e vergonha possibilitaram pensar a liminaridade sentida e expressa nas interpretações dos clientes do Centro Louis Braille sobre o seu processo de reinserção nos jogos sociais.

Eram recorrentes narrativas sobre o processo de distanciamento, a quebra de sentidos compartilhados de afetos e ações no mundo, revelados no isolamento individual e na barreira emocional estabelecida entre o sujeito e o mundo. A perda da visão acarretava conflitos e distanciamentos dos sujeitos de suas esferas de pertença e do rompimento dos laços até então compartilhados. Percebido, por fim, como etapa do luto ou como início das novas articulações intersubjetivas após a perda da visão, o Centro - entendido como espaço de sociabilidade e de dinâmicas e atividades sugeridas pelos professores e monitores - tem para o grupo de pessoas que ali se encontram o papel de um ambiente onde se realiza uma passagem marcante nas suas vidas.

Percebidas como parte da experiência social, as emoções relacionadas ao luto, como o sofrimento e a vergonha, fazem parte de um conjunto de códigos no qual o esforço para um refinamento de gestos e comportamentos dá suporte a uma cadeia de rea- 
ções emocionais. A exposição das narrativas de Anderson, como esforço de compreensão das temporalidades do luto vivenciado e sua relação com as formas de sociabilidade urbanas mostra o diálogo tenso e saturado de conflitos do processo intersubjetivo do personagem nas figurações sociais determinadas. As tensões e conflitos relatados por Anderson e os demais clientes entrevistados, percebidos nas esferas sociais mais públicas ou mesmo privadas do cotidiano, ressaltavam as vivências individuais dos processos de elaboração da perda da visão. Da mesma forma, diversas conversas e entrevistas realizadas com outros clientes do Centro direcionavam as observações às interpretações individuais expressas nas narrativas, mais que a uma discussão dos sentidos de uma identidade grupal ou de um sentimento de pertença coletivo. Mesmo em meio às práticas cotidianas desenvolvidas com certa frequência e em um período de tempo relativamente longo por grupos específicos, ou mesmo entre clientes com histórico de vários anos no Centro, nunca parecia estar em construção uma memória coletiva.

A vergonha, o medo e o estranhamento expressos são anúncios do desconforto, das tensões que qualquer indivíduo ou grupo humano vivencia no cotidiano. A distinção percebida é a negociação de inserção e interação no mundo específica da vivência dos sujeitos que perderam a visão pela sua presença corpórea e suas sensibilidades específicas em prática nas ações cotidianas. A estranheza e a tensão do viver cotidiano são então descortinadas pelas caminhadas e as interpretações daí decorrentes. Nas percepções dos sujeitos em eventos de "re-conhecimento" do mundo cotidiano, a insegurança, a vergonha e o embaraço surgem sem o encobrimento da cotidianidade. Na medida em que se configura como momento de liminaridade no processo de "tornar-se cego", essas primeiras inserções no mundo cotidiano parecem expor o sujeito desprotegido, sensibilizado, em choque, nu, ao mesmo tempo em que expõe o mundo desvelado, aberto em suas tensões às diversas percepções pessoais. 


\section{Referências bibliográficas}

BAUMAN, Richard. Story, performance and event. Cambridge University Press, 1986.

BENJAMIN, Walter. Magia e técnica, arte e política; ensaios sobre literatura e história da cultura. São Paulo: Brasiliense, 1994.

CORREIA, Luiz Gustavo P S.. "A pupila dos cegos é seu corpo inteiro": compreendendo as sensibilidades de indivíduos cegos através das suas tessituras narrativas. 2007. 243 f. Tese. (Doutorado em Antropologia Social). Porto Alegre: Programa de Pós-Graduação em Antropologia Social, Universidade Federal do Rio Grande do Sul. Porto Alegre.

DAMATTA, Roberto. Individualidade e liminaridade: considerações sobre os ritos de passagem e a modernindade. Mana, Rio de Janeiro, vol. 6, n.1, p.7-29, abr. 2000 .

ELIAS, Norbert. 0 processo civilizador - Uma história dos costumes. Rio de Janeiro: Jorge Zahar, 1995.

ELIAS, Norbert. A sociedade de corte. Rio de Janeiro: Jorge Zahar, 2001.

ELIAS, Norbert. A sociedade dos indivíduos. Rio de Janeiro: Jorge Zahar, 1994.

ELIAS, Norbert. A solidão dos moribundos. Rio de Janeiro: Jorge Zahar, 2001.

GIDDENS, Anthony. Modernidade e identidade. Rio de Janeiro: Jorge Zahar, 2002.

KOURY, Mauro Guilherme Pinheiro. Amor e dor - Ensaios em Antropologia Simbólica. Recife: Ed. Bagaço, 2005.

KOURY, Mauro Guilherme Pinheiro. "Cultura e subjetividade: questões sobre a relação luto e sociedade". In: KOURY, Mauro Guilherme Pinheiro; LIMA, Jacob Carlos \& RIFIÓTIS, Theophilos (orgs.). Cultura e subjetividade. João Pessoa: Ed. UFPB, 1996.

KOURY, Mauro Guilherme Pinheiro. Sociologia da emoção. Petrópolis: Vozes, 2003.

MAUSS, Marcel. A expressão obrigatória de sentimentos. In: OLIVEIRA, Roberto Cardoso (org.) Marcel Mauss: Antropologia. São Paulo: Ed. Ática, 1979.

MARTINS, José de Souza. (Des)figurações - A vida cotidiana no imaginário onírico da metrópole. São Paulo: HUCITEC, 1996. 
MARTINS, José de Souza. A sociabilidade do homem simples. São Paulo: HUCITEC, 2000.

MARTINS, José de Souza. Vergonha e decoro na vida cotidiana da metrópole. São Paulo: HUCITEC, 1999.

RICOEUR, Paul. Indivíduo e identidade pessoal. In: Indivíduo e poder. Lisboa: Edições 70, 1988.

RICOEUR, Paul. 0 si mesmo como um outro. Campinas: Papirus, 1991.

RICOEUR, Paul. Tempo e narrativa. 3 vols. Campinas: Papirus, 1994.

TODOROV, Tzvetan. A vida em comum. Campinas: Papirus, 1996.

TURNER, Victor. 0 processo ritual: estrutura e anti-estrutura. Petrópolis: Vozes, 1974. 
